\title{
Larvicidal activity of the water extract of Moringa oleifera seeds against Aedes aegypti and its toxicity upon laboratory animals
}

\author{
PAULO M.P. FERREIRA ${ }^{1}$, ANA F.U. CARVALHO ${ }^{1}$, DAVI F. FARIAS ${ }^{1}$, NARA G. CARIOLANO ${ }^{1}$, \\ VÂNIA M.M. MELO ${ }^{1}$, MARIA G.R. QUEIROZ ${ }^{2}$, ALICE M.C. MARTINS ${ }^{2}$ \\ and JOAQUIM G. MACHADO-NETO ${ }^{3}$ \\ ${ }^{1}$ Departamento de Biologia, Universidade Federal do Ceará, Av. Mister Hall s/n, 60455-970 Fortaleza, CE, Brasil \\ ${ }^{2}$ Departamento de Análises Clínicas e Toxicológicas, Universidade Federal do Ceará, \\ Rua Capitão Francisco Pedro, 1200, 60430-270 Fortaleza, CE, Brasil \\ ${ }^{3}$ Departamento de Defesa Fitossanitária, Universidade Estadual Paulista Júlio de Mesquita Filho, \\ Rod. Prof. Paulo Donato Castellane s/n, 14870-000 Jaboticabal, SP, Brasil \\ Manuscript received on June 6, 2008; accepted for publication on February 17, 2009; \\ presented by SERGIO VERJOVSKI-ALMEIDA
}

\begin{abstract}
In this work, biological effects of the water extract of Moringa oleifera seeds (WEMOS) were assessed on eggs and $3^{\text {rd }}$ instar larvae of Aedes aegypti and on its toxicity upon laboratory animals (Daphnia magna, mice and rats). Crude WEMOS showed a $\mathrm{LC}_{50}$ value of $1260 \mu \mathrm{g} / \mathrm{mL}$, causing $99.2 \pm 2.9 \%$ larvae mortality within $24 \mathrm{~h}$ at $5200 \mu \mathrm{g} / \mathrm{mL}$, though this larvicidal activity has been lost completely at $80^{\circ} \mathrm{C} / 10 \mathrm{~min}$. WEMOS did not demonstrate capacity to prevent egg hatching. After extensive dialyses of the crude WEMOS into water-soluble dialyzable (DF) and nondyalizable (NDF) fractions, only DF maintained its efficacy to kill larvae. Acute toxicity evaluations on daphnids $\left(\mathrm{EC}_{50}\right.$ of $\left.188.7 \mu \mathrm{g} / \mathrm{mL}\right)$ and mice $\left(\mathrm{LD}_{50}\right.$ of $446.5 \mathrm{mg} / \mathrm{kg}$ body weight) pointed out to low toxicity. Despite the thymus hypertrophy, WEMOS revealed to be harmless in orally and subacutely-treated rats. In conclusion, WEMOS has thermostable bioactive compounds against Ae. aegypti larvae with apparent molecular mass lower than $12 \mathrm{kDa}$ and moderately toxic potential.
\end{abstract}

Key words: Aedes aegypti, Daphnia magna, larvicidal activity, Moringa oleifera seeds, toxicity.

\section{INTRODUCTION}

Dengue is an important human viral disease transmitted by Aedes aegypti Linnaeus, 1762 (Diptera: Culicidae) that is gradually becoming endemic in several Central and South American countries (Gubler 1998). Despite the infection with one or more dengue viruses has reached about 2-5 billion people living in tropical and subtropical countries, there are no specific antiviral drugs to treat it and no vaccines to prevent it (Halstead 2007).

Correspondence to: Dr. Paulo Michel Pinheiro Ferreira Present address: Universidade Federal do Piauí, Campus Senador Helvídio Nunes de Barros (CSHNB), sl. 804, Rua Cícero Eduardo s/n, Bairro Junco, 64600-000 Picos, PI, Brasil

E-mails: pmifepe@yahoo.com.br / pmpf@ufpi.edu.br
The Northeast region of Brazil has been suffering successive dengue epidemics, and official reports have demonstrated that the State of Ceará has been one of the most affected states at that region. From 1986 to 2008, a total of 243,619 cases were reported and until last December, 178 out of 185 municipalities were infested (SESA 2008).

The selective pressure of conventional insecticides, such as organochloranes, carbamates, pyrethroids and organophosphorates, is enhancing resistance of mosquito populations at an alarming rate, resulting in widespread resurgence, undesirable effects on non-target organisms and environmental and human health concerns (Brown 1986, Mazzari and Georghiou 1995). This, 
consequently, increases the demand for new products that be environmentally safe, target-specific and easily degradable.

Plant derived products have received much attention due to their natural chemical defenses against insect predators (Carvalho et al. 2003, Omena et al. 2007). However, to be registered as a pesticide, the compounds must be evaluated with respect to their toxicological and ecotoxicological acute and chronic effects under laboratory conditions, in accordance with international standardized procedures (Zucker 1985, OECD 2004).

Moringa oleifera Lamarck, 1785 (Moringaceae), popularly known as horseradish tree and in Latin America as "árbol de rábano" and "quiabo de quina", is a caducifolia South Asian shrub introduced in many parts of the world, like Afghanistan, Bangladesh and in the Americas, from Mexico to Peru, Caribbean Islands, Paraguay and Brazil (Jahn 1988, Gerdes 1997). In Asia, the flowers of $M$. oleifera are mixed together with other foods since they are rich in $\mathrm{Ca}^{2+}, \mathrm{K}^{+}$, waxes, alkaloids, quercetin and kaempferol (Rangaswani and Sankarasubramian 1946, Ramachandran et al. 1980). Leaf extracts show antioxidant and hypocholesterolaemic activities (Iqbal and Bhanger 2006, Chumark et al. 2008). The dry pods have adequate characteristics to be used as a substratum for laboratory animal bedding (Farias et al. 2004). The seeds possess antimicrobial (Ali et al. 2004, Chuang et al. 2007), antitumor (Guevara et al. 1999, Bharali et al. 2003), anti-inflammatory, antispasmodic and diuretic (Cárceres et al. 1992) properties.

Besides uncountable pharmacological uses, water extracts obtained from dry seeds have been used due to their excellent turbid water coagulation properties attributable to the presence of cationic electrolytes (Jahn et al. 1988, Gassenschmidt et al. 1995, Ndabigengesere et al. 1995). In Brazil, seed powder suspension has been introduced efficiently into the Northeast Region due to the tree good adaptation to arid areas as an attempt to improve people hygiene habits and life quality, help to reduce child mortality and collaborate with a sustainable development of the region (Morton 1991, Gerdes 1997, Ferreira et al. 2008).

The aim of this work was to assess the activity of the water extract of M. oleifera seeds (WEMOS) upon egg hatching and larval development of Ae. aegypti and its toxicity on Daphnia magna Straus, 1820 (Cladocera: Crustacea) and laboratory mammals.

\section{MATERIALS AND METHODS}

\section{Plant Material and Extract Preparation}

Moringa oleifera seeds were collected in Fortaleza, State of Ceará, Northeastern Brazil. A voucher specimen $(34,591)$ was authenticated by Dr. Edson de Paula Nunes and deposited at Prisco Bezerra Herbarium (EAC), Departmento de Biologia, Universidade Federal do Ceará.

Recently collected mature dry seeds were dehulled manually and the kernel was crushed in a powder using a pestle and mortar. Seeds with any kind of visible damage were discarded. Distilled water was added to powdered seeds in the proportion of 1 seed $(200 \pm 8.2 \mathrm{mg})$ per $10 \mathrm{~mL}$ of distilled water according to the folk uses in Brazil (Gerdes 1997). The whole mixture was stirred for $60 \mathrm{~min}$ at room temperature $\left(25^{\circ} \mathrm{C}\right)$ using a magnetic stirrer (Fisatom, Brazil) and then filtered through Whatman No. 1 filter paper (Whatman Inc., Clinfton, NJ). All tests took into consideration the soluble solids concentration of the WEMOS, calculated for the mass present in the water extract, which showed a yield of $26 \% \mathrm{w} / \mathrm{w}(26 \mathrm{mg}$ of soluble solids out of $100 \mathrm{mg}$ of powdered seeds).

\section{ANimals}

Eggs and larvae of Ae. aegypti were obtained from NUVET - SESA (Núcleo de Controle de Endemias Transmissíveis por Vetores - Secretaria de Saúde do Estado do Ceará, Fortaleza, Ceará, Brazil), where a laboratory colony is maintained at $25-30^{\circ} \mathrm{C}$ with $80-90 \%$ relative humidity under a photoperiod of $12: 12 \mathrm{~h}$ and free of exposure to pathogens, insecticides or repellents.

Organisms of the D. magna species were cultivated in $2 \mathrm{~L}$ glass dishes with natural water and kept in an incubator at $20 \pm 2^{\circ} \mathrm{C}$ with a $16 \mathrm{~h}$ photoperiod at the Laboratory of Pesticide Ecotoxicology, Departamento de Defesa Fitossanitária, Faculdade de Ciências Agrárias e Veterinárias, São Paulo, Brazil.

Adult Swiss mice (Mus musculus) and Wistar rats (Rattus novergicus) were obtained from the animal facilities of Federal University of Ceará, Brazil. They were kept in well ventilated cages under standard conditions of light (12 h with alternative day and night cycles) and temperature $\left(27 \pm 2^{\circ} \mathrm{C}\right)$ and were housed with access 
to commercial rodent stock diet (Nutrilabor, Campinas, Brazil). The investigational protocol was approved by the Ethical Committee in Animal Research at Universidade Federal of Ceará (Process No. 102/2007) and is in accordance with International Standard on the care and use of experimental animals (EEC Directive of 1986, 86/609/EEC).

\section{Proximate Analysis of Moringa oleifera SEeD}

Total protein, ash and total lipid quantifications were performed according to AOAC (1990). Total carbohydrates (including dietary fiber) were determined by calculating the percentile difference from the total of the other constituents.

\section{Evaluation on EgG Hatching AND LARVAE OF Aedes aegypti}

For egg hatching studies, filter paper containing dehydrated eggs were examined using an ordinary stereo microscope, cut in $1 \mathrm{~cm}^{2}$ pieces with similar quantities of eggs and placed in glass tubes $(20 \mathrm{~mm} \times 100 \mathrm{~mm})$ with $10 \mathrm{~mL}$ in three different concentrations of crude WEMOS (2600, 5200 and $26000 \mu \mathrm{g} / \mathrm{mL})$. Control group was treated with distilled water. To evaluate larvicidal activity, tests were run according to methodology described by WHO (2005), with some modifications. Bioassays were performed with Ae. aegypti larvae on $3^{\text {rd }}$ instar which were collected with a Pasteur pipette, placed on filter paper for removal of excess water and transferred with a tiny brush into $150-\mathrm{mL}$ disposable plastic cups (20 larvae per cup) containing $25 \mathrm{ml}$ of crude WEMOS (375, 750, 1300, 2600 and $5200 \mu \mathrm{g} / \mathrm{mL})$. Three independent experiments were run in quadruplicate and distilled water was used as negative control. Number of hatched eggs, larvae behavior and mortality were verified after $24 \mathrm{~h}$ of treatment at room temperature $\left(25^{\circ} \mathrm{C}\right)$ (Thangam and Kathiresan 1991, Carvalho et al. 2003). Larvae were considered dead if they were immobile and unable to reach the water surface.

\section{Partial Characterization of ACtive Principle}

As an attempt to evidence the nature of substances causing larvae mortality, the WEMOS was submitted to heat treatment $\left(40-80^{\circ} \mathrm{C}\right.$ for $\left.10 \mathrm{~min}\right)$ and thus bioassays using $3^{\text {rd }}$ instar larvae were carried out as described above.
Positive and negative controls were tested with WEMOS not subjected to heat and distilled water, respectively.

Filtered WEMOS was dialyzed extensively (cut off $12 \mathrm{kDa}$ ) for $24 \mathrm{~h}$ against distilled water at $25^{\circ} \mathrm{C}$ in a proportion 1:2 sample: distilled water (non-dialyzable fraction - NDF) with four changes. The water used in the dialysis was frozen by liquid nitrogen, lyophilized and dissolved in distilled water to give $20 \mathrm{mg} / \mathrm{mL}$ (dialyzable fraction - DF). All experiments with the DF and NDF were performed with either fresh preparations or lyophilized material. Soon afterwards, the larvicidal capacity of both NDF and DF was evaluated as described above.

\section{ACUte Toxicity Upon Daphnia magna}

The tests were performed in glass bottles of $30 \mathrm{~mL}$ (4.0 $\mathrm{cm}$ in diameter and $3.5 \mathrm{~cm}$ in height), containing $10 \mathrm{~mL}$ of culture water and thirty neonate daphnids of $24 \mathrm{~h}$ in age exposed to increasing concentrations of the crude WEMOS $(56,130,317$ and $505 \mu \mathrm{g} / \mathrm{mL})$ that were established by preliminary immobility studies (OECD 2004). Feed was provided using a suspension of Scenedesmus subspicatus at the concentration of $5 \times 10^{6}$ cells per organism per day, fermented ration for fish, yeast and a vitamin complex of B1 $(7 \mathrm{mg} / \mathrm{L}), \mathrm{B} 2(7 \mathrm{mg}) / \mathrm{L}, \mathrm{B} 6$ (5 mg/L), B12 (33 mg/L) and H (0.01 mg/L). Immobilized organisms which were incapable of swimming for $15 \mathrm{sec}$ were counted after $24 \mathrm{~h}$ of exposure (Arauco et al. 2005). As a reference substance, it was utilized potassium dichromate (Wako Pure Chemical Industries Ltd.) with $\mathrm{EC}_{50}$ value of $1.42 \mu \mathrm{g} / \mathrm{mL}$.

\section{Acute Toxicity Upon Swiss Mice}

The acute toxicity evaluation was performed on male mice with 20-25 g and 6-8 weeks in age. WEMOS prepared just before injection was administered by intraperitoneal route at different doses $(150,250,400,550$ and $700 \mathrm{mg} / \mathrm{kg}$ body weight). This route was chosen as an effort to avoid interfering factors such as absorption, $\mathrm{pH}$ of the stomach and intestines, enzymatic activity of the digestive tract and first-pass metabolism (Karalliedde et al. 2003). For each dose, eight animals were used and observed during the following $48 \mathrm{~h}$ for detection of any behavioral change, poisonous symptoms and death (Litchfield and Wilcoxon 1949). 


\section{Subacute Toxicity ON Wistar Rats}

Twenty healthy male rats weighing between 180 and $230 \mathrm{~g}$ were randomly divided into two groups $(\mathrm{n}=10$ each). Animals of the experimental group received filtered WEMOS ad libitum $(5200 \mu \mathrm{g} / \mathrm{mL}$ of soluble solids) as the only source of drinking water for continuous 30 days while the control group received tap water. At the end of treatment, animals were anesthetized with halothane (Fluothane, Zeneca, São Paulo, Brazil) and blood samples were collected by retro-orbital puncture (Waynforth 1980) using heparin as anticoagulant. Plasma was separated by centrifuging at $2000 \times$ g for 10 min and kept at $-70^{\circ} \mathrm{C}$ until analysis. Liver subacute toxicity was evaluated by measuring enzyme activity of aspartate aminotransferase (AST), alanine aminotransferase (ALT) and alkaline phosphatase (ALP) after 4 weeks of treatment. All estimations were performed using enzymatic diagnostic reagent kits following manufacturer's instructions (Labtest, Brazil).

Immediately after blood collection, all rats were sacrificed by cervical dislocation. Kidneys, spleen, heart, intestines, stomach, thymus, lungs, liver and pancreas were dissected out, weighed and extensively lyophilized. Subsequently, they were weighted again to determine their dry relative weights. To verify the nitrogen incorporation, rat carcasses were dried at $80^{\circ} \mathrm{C}$ for $48 \mathrm{~h}$, pulverized with an electric grinder (Broun, Mexico) and submitted to nitrogen quantification (AOAC 1990).

\section{Statistical Analyses}

The $\mathrm{EC}_{50}, \mathrm{LC}_{50}$ and $\mathrm{LD}_{50}$ values and their $95 \%$ confidence intervals were obtained using the Trimmed Sperman-Karber method (Hamilton et al. 1979). In order to determine differences between groups, data (means \pm standard deviation) were compared by one-way analysis of variance (ANOVA) followed by Newman-Keuls $(\mathrm{P}<0.05)$ using the GraphPad program (Intuitive Software for Science, San Diego, CA).

\section{RESULTS}

\section{LARVICIDAL ACTIVITY}

The crude WEMOS at $5200 \mu \mathrm{g} / \mathrm{mL}$ (soluble solids) caused $99.2 \pm 2.9 \%$ mortality of $3^{\text {rd }}$ instar larvae within $24 \mathrm{~h}$ and toxic effects were still observed in lower con- centrations, showing an increasing progression toward larvae death in a dose-dependent manner, as described in Table I. Working with soluble solids, this extract revealed a $\mathrm{LC}_{50}$ of $1260 \mu \mathrm{g} / \mathrm{mL}$.

TABLE I

Larvicidal activity of the water extract of Moringa oleifera seeds (WEMOS) upon Aedes aegypti larvae after $24 \mathrm{~h}$ of exposure. Distilled water was used as negative control.

\begin{tabular}{c|c|c|c}
\hline \multirow{2}{*}{$\begin{array}{c}\text { WEMOS } \\
(\mu \mathrm{g} / \mathrm{mL})\end{array}$} & \multicolumn{3}{|c}{ Mortality (\%) } \\
\cline { 2 - 4 } $\begin{array}{c}\text { Negative } \\
\text { control }\end{array}$ & 0.0 & 0.0 & 0.0 \\
\hline 375 & 0.0 & 0.0 & 0.0 \\
\hline 750 & $21.7 \pm 7.5^{\mathrm{a}, \mathrm{b}}$ & 0.0 & 0.0 \\
\hline 1300 & $53.3 \pm 8.9^{\mathrm{a}, \mathrm{b}}$ & 0.0 & $10.6 \pm 6.7^{\mathrm{a}, \mathrm{b}}$ \\
\hline 2600 & $86.7 \pm 6.5^{\mathrm{a}, \mathrm{b}}$ & 0.0 & $55.2 \pm 9.8^{\mathrm{a}, \mathrm{b}}$ \\
\hline 5200 & $99.2 \pm 2.9^{\mathrm{a}, \mathrm{b}}$ & 0.0 & $97.5 \pm 3.3^{\mathrm{a}, \mathrm{b}}$ \\
\hline
\end{tabular}

WEMOS is expressed as soluble solids based on the proportion 1 seed: $10 \mathrm{~mL}$ (Gerdes 1997). Values are means \pm S.D. of three independent experiments performed in quadruplicate. NDF - Non-dialyzable fraction; $\mathrm{DF}-$ Dialyzable fraction. ${ }^{\mathrm{a}} \mathrm{P}<0.05$, compared to control by one-way analysis of variance (ANOVA) followed by Newman-Keuls test. ${ }^{b_{P}}<0.05$, compared to the immediately lower concentration by one-way analysis of variance (ANOVA) followed by NewmanKeuls test.

The crude WEMOS was further fractionated and corresponding fractions were analyzed separately. After extensive dialysis for $24 \mathrm{~h}$, the NDF of WEMOS was ineffective to cause larval death. On the other hand, concentration-dependent outcomes were also obtained with the DF of WEMOS, which caused larval mortality that ranged from 10.6 (at $1300 \mu \mathrm{g} / \mathrm{mL}$ ) to $97.5 \%$ (at $5200 \mu \mathrm{g} / \mathrm{mL}$ ). Although the highest concentration has been capable to kill nearly $100 \%$ larvae, deaths had begun at higher concentrations (at $1300 \mu \mathrm{g} / \mathrm{mL}$ ) than those seen with crude WEMOS, suggesting that some activity had been lost after dialysis. The larvicidal activity was significantly diminished after heat treatment at 60 , 70 and $80^{\circ} \mathrm{C} / 10 \mathrm{~min}$, leading to larvae mortality rates of $70.0 \pm 8.2,60.0 \pm 11.5$ and $0 \%$, respectively $(\mathrm{P}<$ $0.05)$. No deaths occurred in the negative control. Meanwhile, non-heated WEMOS showed $97.3 \pm 2.0 \%$ mortality. In spite of the larvicidal activity, crude WEMOS showed no capacity to interfere on egg hatching (Ta- 
ble II) not even when tested at five-fold the concentration that caused $100 \%$ mortality $(\mathrm{P}>0.05)$. However, none of the newly hatched larvae was able to reach its second stage, given that all died after hatching at all tested concentrations $(\mathrm{P}<0.05)$ (Table II).

\section{TABLE II}

Evaluation of of the water extract of Moringa oleifera seeds (WEMOS) on egg hatching of Aedes aegypti after $24 \mathrm{~h}$ of exposure. Distilled water was used as negative control.

\begin{tabular}{c|c|c|c}
\hline $\begin{array}{c}\text { Crude } \\
\text { WEMOS } \\
(\mu \mathrm{g} / \mathrm{mL})\end{array}$ & $\begin{array}{c}\text { Number of } \\
\text { eggs }\end{array}$ & $\begin{array}{c}\text { Hatching } \\
(\%)\end{array}$ & $\begin{array}{c}\text { Larvae } \\
\text { mortality on } \\
\text { 1st instar }(\%)\end{array}$ \\
\hline $\begin{array}{c}\text { Negative } \\
\text { control }\end{array}$ & $51.6 \pm 2.0$ & $72.6 \pm 10.1$ & 0.0 \\
\hline 2600 & $50.6 \pm 2.8$ & $74.5 \pm 10.8$ & $100^{\mathrm{a}}$ \\
\hline 5200 & $49.4 \pm 1.3$ & $74.6 \pm 12.7$ & $100^{\mathrm{a}}$ \\
\hline 26000 & $49.3 \pm 2.3$ & $79.4 \pm 10.9$ & $100^{\mathrm{a}}$ \\
\hline
\end{tabular}

WEMOS is expressed as soluble solids based on the proportion 1 seed: $10 \mathrm{~mL}$ (Gerdes 1997). Values are means \pm S.D. of three independent experiments performed in quadruplicate. ${ }^{\mathrm{a}} \mathrm{P}<0.05$, compared to control by one-way analysis of variance (ANOVA) followed by Newman-Keuls test.

\section{TOXICITY ASSAYS}

The evaluation of the WEMOS on Daphnia magna showed, based on the $\mathrm{r}^{2}$ values (0.99), a high linear relationship ( $\mathrm{Y}=0.19 \mathrm{X}+5.61)$ between immobility of the test organisms and concentrations of the WEMOS, which presented an $\mathrm{EC}_{50}$ of $188.7 \mu \mathrm{g} / \mathrm{mL}$ (Table III).

In the studies of acute toxicity on mice, no external manifestation of toxic syndrome was observed within $48 \mathrm{~h}$ after injection of a single dose of WEMOS 150 $\mathrm{mg} / \mathrm{kg}$ body weight. Although no deaths occurred at doses of 250 and $400 \mathrm{mg} / \mathrm{kg}$, some mice (7 out of 16) showed diarrhea after $24 \mathrm{~h}$. On the other hand, deaths were noticed at $550 \mathrm{mg} / \mathrm{kg}$ (5 out of 8 ) and $700 \mathrm{mg} / \mathrm{kg}$ (100\% mortality) between $10-36 \mathrm{~h}$ following inoculation. Subsequent statistic analyses calculated a $\mathrm{LD}_{50}$ of 446.5 (418.3-476.6) $\mathrm{mg} / \mathrm{kg}$ body weight.

As described in Table IV, the subacute treatment of rats with WEMOS given ad libitum for 30 days did not cause changes on the AST, ALT and ALP serum values when compared to the control group $(\mathrm{P}>0.05)$.

Seed proximate composition ( $\mathrm{g} / \mathrm{kg}$ dry matter) shows high levels of total proteins $(377.5 \pm 1.90 \mathrm{~g} / \mathrm{kg})$, total lipids $(363.2 \pm 2.6 \mathrm{~g} / \mathrm{kg})$, ash $(35.8 \pm 2.6 \mathrm{~g} / \mathrm{kg})$ and total carbohydrates $(223.5 \mathrm{~g} / \mathrm{kg})$. This protein level was probably reflected on the nitrogen incorporation by the WEMOS-treated animals $(67.5 \pm 2.5 \mathrm{~g} / 100 \mathrm{~g}$ body weight) in comparison with the control group (59.5 \pm $3.0 \mathrm{~g} / 100 \mathrm{~g}$ body weight $)(\mathrm{P}<0.05)$. Nevertheless, there was no statistical difference on body weight gain between oral WEMOS-treated $(90.7 \pm 16.0 \mathrm{~g})$ and non-treated $(89.0 \pm 8.4 \mathrm{~g})$ rats $(\mathrm{P}>0.05)$ and neither mortality nor morbidity was recorded during the whole experiment. Most of the organs did not show alterations in their relative weights (Table V), though thymus of the treated group displayed increasing in both wet $(0.08 \pm 0.02 \mathrm{~g})$ and dry $(0.17 \pm 0.03 \mathrm{~g})$ relative weights when compared to the controls $(0.05 \pm 0.01 \mathrm{~g}$ and $0.11 \pm 0.02 \mathrm{~g}$ for wet and dry relative weights, respectively) $(\mathrm{P}<0.05)$.

\section{DISCUSSION}

The mosquito Aedes aegypti has domiciliary habits, hiding in dark and closed places, which leads to difficulties in its eradication (Gubler 1998). So, the most efficient way to control dengue resides in preventing the insect breeding through the use of larvicides (Consoli and Oliveira 1994, WHO 1999). In this work, we showed that the crude WEMOS and its soluble dialyzable fraction (DF) separated by dialysis membrane (cut off $12 \mathrm{kDa}$ ) were toxic to the larvae. These results suggest the participation of low molecular mass compounds in the DF as responsible for these larvicidal effects on Ae. aegypti. Previously, it was confirmed the presence of proteins by the Bradford method and by tricine-sodium dodecyl sulfate polyacrylamide gel electrophoresis with apparent molecular mass ranging from 6 to $30 \mathrm{kDa}$ in both crude WEMOS and DF (Ferreira 2004). These findings are in line with Gassenschmidt et al. (1995), Ndabigengesere et al. (1995) and Gomes (A.S. Gomes, unpublished data) who identified, by different techniques, proteins lower than $13 \mathrm{kDa}$ in the seeds. To evidence facts to support this hypothesis, crude WEMOS was heat-treated prior to exposure to $3^{r d}$ instar larvae. WEMOS lost its toxic effects on larvae completely between $70-80^{\circ} \mathrm{C}$, suggesting being reasonable to consider that the protein fraction may be involved in the larvicidal activity.

We also demonstrated that WEMOS was not efficient to interfere in hatching of Ae. aegypti eggs in $24 \mathrm{~h}$ 
TABLE III

Linear regression analysis of immobility tests performed on Daphnia magna organisms and the $\mathbf{E C}_{(50-24 h)}$ value with lower (LI) and upper (UI) $95 \%$ confidence intervals calculated for the water extract of Moringa oleifera seeds (WEMOS).

\begin{tabular}{c|c|c|c|c}
\hline Test agent & Linear equation & $\mathrm{R}^{2}$ & $\begin{array}{c}\mathrm{EC}_{(50-24 \mathrm{~h})} \\
(\mu \mathrm{g} / \mathrm{mL}) \\
(\mathrm{LI}-\mathrm{UI})\end{array}$ & $\begin{array}{c}\text { Toxicity class } \\
(\text { Zucker 1985) }\end{array}$ \\
\hline WEMOS & $\mathrm{Y}=0.19 \mathrm{X}+5.61$ & 0.99 & $\begin{array}{c}188.7 \\
(130.2-273.7)\end{array}$ & $\begin{array}{c}\text { Practically } \\
\text { non toxic }\end{array}$ \\
\hline
\end{tabular}

$\mathrm{EC}_{50}$ value was obtained from three independent experiments and analyzed by the Trimmed Sperman-Karber method (Hamilton et al. 1979).

exposure. Indeed, after $48 \mathrm{~h}$, the egg embryonic development of Ae. aegypti is usually completed, an event which can explain egg resistance during adverse conditions, and this turns the eggs the most resistant phase of its life cycle (WHO 1999).

\section{TABLE IV}

Hepatic enzyme activity of aspartate aminotransferase (AST), alanine aminotransferase (ALT) and alkaline phosphatase (ALP) after the oral treatment of rats with water extract of Moringa oleifera seeds (WEMOS) ad libitum during 30 days. Control group received tap water.

\begin{tabular}{c|c|c|c}
\hline \multirow{2}{*}{ Groups } & \multicolumn{3}{|c}{ Enzyme activity (U/L) } \\
\cline { 2 - 4 } & AST & ALT & ALP \\
\hline Control & $57.0 \pm 20.5$ & $22.9 \pm 7.6$ & $84.1 \pm 7.8$ \\
\hline WEMOS & $65.1 \pm 11.1$ & $30.4 \pm 7.5$ & $78.4 \pm 8.0$ \\
\hline
\end{tabular}

Values are means \pm S.D., $\mathrm{n}=10$ animals/group.

In order to evaluate environmental impacts of the extract, we performed some acute toxicological tests to understand its potential as a toxicant. Ecotoxicologic assessment was carried out on Daphnia magna, a cladoceran crustacean commonly used for determining the toxicity of pollutants and very recommended for representing aquatic invertebrates (OECD 2004). Moreover, it shows a defined sensitivity to reference substances and has laboratorial advantages in its utilization such as short life cycle, parthenogenesis reproduction and ease of handling (Tatarazako and Oda 2007).

According to the acute toxicity classes proposed by Zucker (1985), moringa seeds were practically nontoxic on daphnids, with a $\mathrm{EC}_{50}$ of $188.7 \mu \mathrm{g} / \mathrm{mL}$. Recently, using laboratory-cultured Artemia nauplii as an alternative tool to preliminary assessment of WEMOS toxicity, we found similar results and a $\mathrm{LC}_{50}$ value of $177.8 \mu \mathrm{g} / \mathrm{mL}$ (Ferreira et al. 2007). Ali et al. (2004) have already demonstrated that $M$. oleifera seed extracts are toxic to the green microalga Scenedesmus obliquus. Additionally, the assay of acute toxicity on mice showed that WEMOS has an $\mathrm{LD}_{50}(446.5 \mathrm{mg} / \mathrm{kg}$ body weight) that is considered only moderately toxic when compared to toxicological human standards (Hodge and Sterner 1944).

Some populations in developing countries do not have access to treated water and so they store water for daily consumption, which facilitates mosquito oviposition and proliferation. Thus, to further assess the safety of moringa seeds, some physiological parameters were monitored in rats receiving WEMOS as the unique source of drinking water during 30 days. The ad libitum intake was in the range of $1300-1670 \mathrm{mg} / \mathrm{kg} /$ day and no alterations were observed in the hepatic enzymes (ALT, AST and ALP), which confirms our recent results showing the lack of hepatotoxicity in rats after the administration of WEMOS at $400 \mathrm{mg} / \mathrm{kg} /$ day for 30 days (Ferreira et al. 2007). The enzymes ALT, AST and ALP are commonly used as markers of hepatic damage and the degree and type of liver injuries can be evaluated based on the presence or absence of these specific enzymes in the bloodstream (Kumar et al. 2004). On the other hand, Bharali et al. (2003) reported that administration of the hydroalcoholic extract of $M$. oleifera drumsticks by oral route enhanced levels of some hepatic enzymes involved in detoxification of xenobiotic substances, such as carcinogens and plant venomous compounds. Thereafter, Gupta et al. (2005) have described 
TABLE V

Organ relative weights of rats treated with water extract of Moringa oleifera seeds (WEMOS) ad libitum during 30 days. Control group received tap water.

\begin{tabular}{l|c|c|c|c}
\hline \multirow{2}{*}{ Organs } & \multicolumn{2}{|c|}{ Control group } & \multicolumn{2}{c}{ WEMOS group } \\
\cline { 2 - 5 } & \multicolumn{2}{|c}{ Relative weight $(\mathrm{g} / 100 \mathrm{~g}$ body mass) } \\
\cline { 2 - 5 } & Wet & Dry & Wet & Dry \\
\hline Liver & $2.04 \pm 0.14$ & $4.80 \pm 0.24$ & $2.06 \pm 0.14$ & $4.91 \pm 0.59$ \\
\hline Pancreas & $0.12 \pm 0.02$ & $0.35 \pm 0.07$ & $0.10 \pm 0.02$ & $0.29 \pm 0.04$ \\
\hline Stomach & $0.29 \pm 0.02$ & $0.55 \pm 0.05$ & $0.29 \pm 0.03$ & $0.55 \pm 0.08$ \\
\hline Small intestine & $1.29 \pm 0.17$ & $2.49 \pm 0.27$ & $1.25 \pm 0.11$ & $2.42 \pm 0.19$ \\
\hline Large intestine & $0.70 \pm 0.11$ & $1.28 \pm 0.20$ & $0.67 \pm 0.05$ & $1.26 \pm 0.11$ \\
\hline Thymus & $0.05 \pm 0.01$ & $0.11 \pm 0.02$ & $0.08 \pm 0.02^{\mathrm{a}}$ & $0.17 \pm 0.03^{\mathrm{a}}$ \\
\hline Kidneys & $0.37 \pm 0.03$ & $0.78 \pm 0.07$ & $0.37 \pm 0.03$ & $0.76 \pm 0.05$ \\
\hline Heart & $0.13 \pm 0.01$ & $0.26 \pm 0.01$ & $0.14 \pm 0.01$ & $0.28 \pm 0.01$ \\
\hline Lungs & $0.19 \pm 0.02$ & $0.37 \pm 0.04$ & $0.18 \pm 0.03$ & $0.35 \pm 0.05$ \\
\hline Spleen & $0.09 \pm 0.01$ & $0.21 \pm 0.03$ & $0.10 \pm 0.01$ & $0.21 \pm 0.02$ \\
\hline
\end{tabular}

Values are means \pm S.D., $\mathrm{n}=10$ animals/group. ${ }^{\mathrm{a}} \mathrm{P}<0.05$, compared to control by one-way analysis of variance (ANOVA) followed by Newman-Keuls test.

the capacity of moringa seeds to protect animals against oxidant stress caused by arsenic exposure. In truth, several researches attributed this oxidative protection of the seeds to the presence of compounds with antioxidant activity against free radicals (Geervani and Devi 1981, Siddhuraju and Becker 2003) that confer a promising chemo-preventive potential (Guevara et al. 1999, Bharali et al. 2003). Despite various reports have suggested hepatoprotective action of different parts of $M$. oleifera (Ruckmani et al. 1998, Fakurazi et al. 2008), further investigations must be done to confirm this property in the seeds.

Organs of WEMOS-treated rats presented neither macroscopic alterations nor modifications on their relative weight, with exception of the thymus increase. Interestingly, we have seen previously that administration of WEMOS $400 \mathrm{mg} / \mathrm{kg}$ promotes spleen hypertrophy (Ferreira et al. 2007). These findings suggest that this extract probably has substances implied in the leukocyte activation and/or immunological amplification (Imboden 1988, Santos et al. 2005). On the other hand, contrasting results were obtained by Oliveira et al. (1999), who, in a 10 day-feeding trial substituting $M$. oleifera seed flour for egg-white standard protein, showed adverse effects such as decreased body weight and food intake and changes on internal organs, such as hyper- trophy of stomach, small intestine, liver, pancreas, kidneys, heart and lungs and atrophy of thymus and spleen. The seeds possess hemagglutinating activity, glucosinolates $(65.5 \mu \mathrm{mol} / \mathrm{g})$ and phytates $(41 \mathrm{~g} / \mathrm{kg})$ (Makkar and Becker 1997, Oliveira et al. 1999, Santos et al. 2005) which may be responsible for the observed adverse effects. Nevertheless, the present work did not reveal toxic activity on the rats, suggested by observed normal growth and absence of body and organ weight changes. Quite the opposite, moringa group demonstrated significantly higher body nitrogen levels.

Besides low toxicity, the multiple purpose crude WEMOS has been presented to be advantageous when compared to inorganic or synthetic organic coagulants, being as efficient as aluminum salts for coagulation of raw water (Ndabigengesere and Narasiah 1998), dramatically decreasing clay and bacteria contents (Madsen et al. 1987, Broin et al. 2002, Ghebremichael et al. 2005). It brings advantages in relation to flocculant polymers which are associated with human pathologies, particularly health problems related to residual aluminum like Alzheimer's disease (Martyn et al. 1989) and promotion of carcinogenesis (Mallevialle et al. 1984). Now, this cleaning water property can be combined with its larvicidal action against Ae. aegypti, the dengue urban vector main and a highly domestic tropical mosquito that 
prefers to lay its eggs in artificial containers commonly found in and around human dwellings, such as flower vases, water storage containers and buckets that collect rainwater (for example, empty bottles, old automobile tires and trash in general) (Consoli and Oliveira 1994), all important places in producing large numbers of larvae which may be exterminated by WEMOS.

Our study clearly demonstrated that water extract of Moringa oleifera seeds have lethal action against Aedes aegypti larvae and low toxic effects on laboratorial animals, which is in agreement with the literature (Berger et al. 1984, Grabow et al. 1985, Ali et al. 2004, Ferreira et al. 2007). These advantages encourage the dispersion of $M$. oleifera tree around the world as well as the exploitation of its seed as a way to reduce the exorbitant costs of water treatment, mainly in developing countries and rural areas (Jahn et al. 1988). An additional benefit is that $M$. oleifera seed is available throughout the year, especially when the mosquito population is higher. The plants grow in nature without any extra care or cost and simple technology would be necessary to separate the most suitable fractions to be exploited as a possible chemical to be employed in mosquito control programs. Further investigations are in progress to identify the moringa larval-killing compound(s).

\section{ACKNOWLEDGMENTS}

The authors are grateful for the technical assistance of Berenice Alves. This investigation was supported by grants from Fundação Cearense de Amparo à Pesquisa (FUNCAP) and Conselho Nacional de Desenvolvimento Científico e Tecnológico/Departamento de Ciência e Tecnologia (CNPq/DECIT), agencies from Brazil.

\section{RESUMO}

Neste trabalho, o extrato aquoso das sementes de Moringa oleifera (EASMO) foi avaliado quanto aos seus efeitos biológicos sobre ovos e larvas de Aedes aegypti no $3^{\circ}$ estágio de desenvolvimento e sua toxicidade sobre animais de laboratório (Daphnia magna, camundongos e ratos). O EASMO bruto revelou uma $\mathrm{CL}_{50}$ de $1.260 \mu \mathrm{g} / \mathrm{mL}$, causando $99,2 \pm 2,9 \%$ de mortalidade em $24 \mathrm{~h}$ na concentração de $5.200 \mu \mathrm{g} / \mathrm{mL}$, embora o mesmo não tenha sido capaz de impedir a eclosão dos ovos. A atividade larvicida extinguiu-se após aquecimento do extrato a $80^{\circ} \mathrm{C} / 10$ min. Diálises sucessivas do EASMO bruto resul- taram em duas frações solúveis em água (Fração dializável, FD; Fração não-dializável, FND), dentre as quais apenas a FD mostrou ação larvicida. Testes de toxicidade aguda realizados em dáfnias ( $\mathrm{CE}_{50}$ de 188, $7 \mu \mathrm{g} / \mathrm{mL}$ ) e camundongos $\left(\mathrm{DL}_{50}\right.$ de $446,5 \mathrm{mg} / \mathrm{kg}$ de peso corpóreo) evidenciaram baixa toxicidade. Apesar da hipertrofia tímica, o EASMO mostrou ser atóxico após tratamento subagudo via oral em ratos. Conclui-se, portanto, que o EASMO apresenta substâncias com capacidade larvicida contra Ae. aegypti, as quais possuem massa molecular aparente menor que $12 \mathrm{kDa}$ e potencial tóxico moderado.

Palavras-chave: Aedes aegypti, Daphnia magna, atividade larvicida, sementes de Moringa oleifera, toxicidade.

\section{REFERENCES}

Ali GH, El-Taweel GE And Ali MA. 2004. The cytotoxicity and antimicrobial efficiency of Moringa oleifera seeds extracts. Intern J Environ Studies 61: 699-708.

AOAC - Association Of OfFicial AnAlyticAl CHEMISTS. 1990. Official Methods of Analysis of the Association of Official Analytical Chemists. Arlington: The Association, $1278 \mathrm{p}$.

Arauco LRR, Cruz C And Machado-Neto JG. 2005. Efeito da presença de sedimento na toxicidade aguda do sulfato de cobre e do triclorfon para três espécies de Daphnia. Pesticidas: Rev Ecotox Meio Amb 15: 55-64.

Berger MR, Habs M, JAHn SAA AND Schmahl D. 1984. Toxicological assessment of seeds from Moringa oleifera and Moringa stenopetala, two highly efficient primary coagulants for domestic water treatment of tropical raw waters. East Afr Med J 61: 712-716.

Bharali R, TABAssum J AND AzAd MR. 2003. Chemomodulatory effect of Moringa oleifera Lam. on hepatic carcinogen metabolising enzymes, antioxidant parameters and skin papillomagenesis in mice. Asian Pac J Cancer Prev 4: 131-139.

Broin M, Santaella C, Cuine S, Kokou K, Peltier G AND JOËT T. 2002. Flocculent activity of a recombinant protein from Moringa oleifera Lam. seeds. Appl Microbiol Biotechnol 60: 114-119.

BROWN AWA. 1986. Inseticide resistance in mosquitoes: a pragmate review. J Am Mosq Control Assoc 2: 123-139.

Cárceres A, Saraiva A, Rizzio S, Zabala L, De LEON E AND NAVY F. 1992. Pharmacological properties of Moringa oleifera. 2: Screening for antispasmodic, anti-inflammatory and diuretic activity. J Ethnopharmacol 36: 233-237. 
Carvalho afFu, Melo VMM, Craveiro AA, MaCHADO MIL, BANTIM MB AND RABELO EF. 2003. Larvicidal Activity of the Essencial Oil from Lippia sidoides Cham. agaisnt Aedes aegypti Linn. Mem Inst Osw Cruz 98: 569-571.

Chumark P, Khunawat P, Sanvarinda Y, PhornchiRASilP S, MORALES NP, PHIVTHONGNGAM L, RATANACHAMNONG P, SRISAWAT S AND PONGRAPEEPORN KS. 2008. The in vitro and ex vivo antioxidant properties, hypolipidaemic and antiatherosclerotic activities of water extract of Moringa oleifera Lam. leaves. J Ethnopharmacol 116: 439-446.

Consoli RAGB and Oliveira RL. 1994. Principais Mosquitos de Importância Sanitária no Brasil. Rio de Janeiro: Fiocruz, $225 \mathrm{p}$.

Chuang PH, Lee CW, Chou Jy, Murugan M, Shieh BJ AND CHEN HM. 2007. Anti-fungal activity of crude extracts and essential oil of Moringa oleifera Lam. Bioresour Technol 98: 232-236.

EEC Directive of 1986. Council Directive of 24 November 1986 on the approximation of laws, regulations and administrative provisions of the Member States regarding the protection of animals used for experimental and other scientific purposes (86/609/EEC).

FAKURAzi S, ITHINin H AND GaUdar UNL. 2008. Moringa oleifera Lam prevents acetaminophen induced liver injury through restoration of glutathione level. Food Chem Toxicol 46: 2611-2615.

FARIAS DF, BRASIL ICF, FERREIRA PMP AND CARVALHO AFFU. 2004. Potencialidade da vagem de Moringa oleifera Lam. como cama de animais de laboratório. Rev Univ Rural 24: 201-202.

FERrEIRA PMP. 2004. Atividade Larvicida do Extrato Aquoso de Moringa oleifera Lamarck contra Aedes aegypti Linnaeus: Identificação Parcial e Caracterização Toxicológica do Princípio Ativo. Universidade Federal do Ceará, Departamento de Biologia, 70 p.

Ferreira PMP, Carvalho AFFU, Sousa DF, MagaLhães JF, MARTINS AR, MARTINS AMC AND QUEIROZ MGR. 2007. Water extract of Moringa oleifera seeds: a toxicological approach. REPM 1: 45-57.

FERREIRA PMP, FARIAS DF, OLIVEIRA JTA AND CARVALHO AFFU. 2008. Moringa oleifera: Bioactive compounds and nutritional potential. Rev Nutr 21: 431-437.

Gassenschmidt U, JANY KD, TAUSChER B AND NiERBERGALL H. 1995. Isolation and caracterization of a flocculating protein from Moringa oleifera Lam. Biochim Biophys Acta 1243: 477-481.
GeERVANi P AND DEVI A. 1981. Influence of protein and fat on utilization of carotene from drumstick (Moringa oleifera) leaves. Indian J Med Res 74: 548-553.

Gerdes C. 1997. Como limpar e tratar água suja com sementes de Moringa oleifera, Centro de Fortaleza: Centro de Pesquisa e Assessoria, 18 p.

Ghebremichael KA, Gunaratna KR, Henriksson H, Brumer H ANd Dalhammar G. 2005. Simple purification and activity assay of the coagulant protein from Moringa oleifera seed. Water Res 39: 2338-2344.

Grabow WOK, Slabert JL, MORGan WSG AND JAHN SAA. 1985. Toxicity and mutagenicity evaluation of water coagulated with Moringa oleifera seed preparations using fish, protozoan, bacterial, coliphage, enzyme, and Ames Salmonella assays. Water SA 11: 9-14.

Gubler DJ. 1998. Dengue and Dengue Hemorrhagic Fever. Clin Microbiol Rev 11: 480-496.

Guevara a P, Vargas C, Sakurai H, Fujiwara Y, Hashimoto K, MaOKa T, KozUKa M, Ito Y, TOKUdA H AND Nishino H. 1999. An antitumor promoter from Moringa oleifera Lam. Mutation Res 440: 181-188.

Gupta R, Kannan GM, Sharma M and Flora SJS. 2005. Therapeutic effects of Moringa oleifera on arsenicinduced toxicity in rats. Environ Toxicol Pharmacol 20: 456-464.

Halstead SB. 2007. Dengue. Lancet 370: 1644-1652.

Hamilton MA, Russo RC AND Thurston RV. 1979. Trimmed Spearmann-Karber method for calculation of $\mathrm{EC}_{50}$ and $\mathrm{LC}_{50}$ values in bioassays. Environ Sci Technol 7: 114-119.

Hodge HC AND Sterner JH. 1944. Tabulation of toxicity classes. Am Ind Hyg Assoc 10: 94-97.

IMBODEN JB. 1988. The regulation of intracellular signals during lymphocyte activation. Immunol Today 9: 17-18.

IQBAL S AND BHANGER MI. 2006. Effect of season and production location on antioxidant activity of Moringa oleifera leaves grown in Pakistan. J Food Comp Anal 19: 544-551.

JAHN SAA. 1988. Using Moringa seeds as coagulants in developing countries. J Am Water Works Assoc 90: 4350.

Karalliedde LD, Edwards P AND Marris TC. 2003. Variables influencing the toxic response to organophosphates in humans. Food Chem Toxicol 41: 1-13.

Kumar V, Abbas AK, Fausto N, Robbins SL And Cotran RS. 2004. Pathology Basis of Disease. China: WB Saunders, 1592 p. 
LitCHFIELD JJT AND WilcoXon FA. 1949. A simplified method for evaluation of dose-effect experiments. J Pharmacol Exp Ther 96: 99-103.

MAdsen M, ACHLUndt J AND OMER EF. 1987. Effect of water coagulation by seeds of Moringa oleifera on bacterial concentrations. J Trop Med Hyg 90: 101-109.

MAKKAR HPS AND BECKER K. 1997. Nutrients and antiquality factors in different morphological parts of the Moringa oleifera tree. J Agric Sci 128: 311-322.

Mallevialle J, Bruchet A And Fiessinger F. 1984. How safe are organic polymers in water treatment. JAWWA 76: 431-436.

MARTYN CN, BARKER DJP, OSMOND C, HARRIS EC, EDWARDSON JA AND LACEY RF. 1989. Geographical relation between Alzheimer's disease and aluminum in drinking water. Lancet 1: 59-62.

Mazzari MB AND GeOrghiou GP. 1995. Characterization of resistance to organophosphate, carbamate, and pyrethroid insecticides in field populations of Aedes aegypti from Venezuela. J Am Mosq Control Assoc 11: 315-322.

MORTON JF. 1991. The horseradish tree, Moringa pterygosperma (Moringaceae) - A boon to arid lands? Econ Bot 45: 318-333.

Ndabigengesere A, Narasiah KS and Talbot BG. 1995. Active agents and mechanism of coagulation of turbid waters using Moringa oleifera. Water Res 29: $703-710$.

NdABIGEngesere A AND NARAsiah KS. 1998. Quality of water treated by coagulation using Moringa oleifera seeds. Water Res 32: 781-791.

OECD - ORGANIZATION FOR ECONOMIC CO-OPERATION AND DeVElopment. 2004. Guidelines for Testing of Chemicals. Guideline 202: Daphnia sp. Acute Immobilisation Test. Paris, France, p. 260-275.

Omena MC, NaVArRo DMAF, PAula JE, Luna JS, FerREIRA DE LIMA MR AND SANT'ANA AEG. 2007. Larvicidal activities against Aedes aegypti of some Brazilian medicinal plants. Bioresour Technol 98: 2549-2556.

Oliveira JTA, Silveira SB, VAsconcelos IM, CAVADA BS AND MOREIRA RA. 1999. Compositional and nutritional attributes of seeds from the multiple purpose tree Moringa oleifera Lamarck. J Sci Food Agric 79: 815-820.
Ramachandran C, Peter KV And Gopalakrishnan PK. 1980. Drumstick (Moringa oleifera): a multipurpose Indian vegetable. Econ Bot 34: 276-283.

RANGASWANI S AND SANKARASUBRAMIAN S. 1946. Chemical components of the flowers of Moringa pterygosperma. Curr Sci 5: 316-320.

RUCKMANi K, KAVIMANi S, ANANDAN R AND JAYAKAR B. 1998. Effect of Moringa oleifera Lam on paracetamolinduced hepatotoxicity. Indian J Pharm Sci 60: 33-35.

Santos AFs, Argolo ACC, Coelho LCBB And PAiva PMG. 2005. Detection of water soluble lectin and antioxidant component from Moringa oleifera seeds. Water Res 39: 975-980.

SESA - Secretaria de Saúde do Estado do Ceará. 2008. Informe Semanal de Dengue. Fortaleza: Núcleo de Vigilância Epidemiológica, Governo do Estado do Ceará, $10 \mathrm{p}$.

Siddhuraju P ANd Becker K. 2003. Antioxidant properties of various solvent extracts of total phenolic constituents from three different agroclimatic origins of drumsticks tree (Moringa oleifera Lam.) leaves. J Agric Food Chem 51: 44-55.

TATARAZAKo N AND OdA S. 2007. The water flea Daphnia magna (Crustacea, cladocera) as a test species for screening and evaluation of chemicals with endocrine disrupting effects on crustaceans. Ecotoxicol 16: 197-203.

ThANGAM TS AND KATHIRESAN K. 1991. Mosquito larvicidal effect of seaweed extracts. Bot Mar 34: 433-435.

WAYNFORTH BH. 1980. Injection Techniques: Experimental and Surgical Techniques in the Rat. London: Academic Press, $61 \mathrm{p}$.

WHO - World Health Organization. 1999. Prevention and Control of Dengue and Dengue Haemorrhagic Fever, No 29. Comprehensive Guidelines, New Delhi, India, $134 \mathrm{p}$.

WHO - World Health Organization. 2005. Guidelines for Laboratory and Field Testing of Mosquito Larvicides. Geneva, Switzerland, 41 p.

ZUCKER E. 1985. Standard evaluation procedure-Acute toxicity test for freshwater fish. Washington: USEPA 540/985-006, $17 \mathrm{p}$. 